\section{LOSS OF APPETITE IN UREA CYCLE DISORDERS (UCD):}

$\dagger 1213$ THERAPEUTIC APPROACHES - Susan Hyman, Mark L. Batshaw, Joseph Coyle, cynthia Porter and Claude Bachmann. Dept. of Pediat., Psych, and Kennedy Inst., John
Hopkins Med. Inst. Balto. and Dept. of Clin. Chem. Berne.
Howerammonemic animals have decreased food intake and Hyperammonemic animals have decreased food intake and
ncreased serotonin (5-HT) and its metabolite 5-hydroxy increased serotonin (5-HT) and its metabolite 5-hydroxy ${ }_{1983}$. Whe 2 anorectic children with UCD with precursor restriction and antiserotonergic drugs. A 7 yo. with argininorestriction and antiserotonergic arugs. A succinic aciduria refused all oral feedings and ha eseviction levels of HIAA in CSF $(78 \mathrm{ng} / \mathrm{m} 1)$. She responded to restriction
of dietary tryptophan, $\operatorname{Trp}(7 \mathrm{vs} .34 \mathrm{mg} / \mathrm{kg} / \mathrm{d})$ with the onset of of dietary tryptophan, Trp (7 vs. $34 \mathrm{mg} / \mathrm{kg} / \mathrm{d}$ ) with the onset
spontaneous food intake. She was then treated with the $5-\mathrm{HT}$ receptor blocker cyproheptadine (Cyp), $0.3 \mathrm{mg} / \mathrm{kg} / \mathrm{d}$, while receiving $14 \mathrm{mg} / \mathrm{kg} / \mathrm{d}$ Trp. Food Intake during a $5 \mathrm{~min}$. free feeding condition was increased under both of the low $\operatorname{Trp}$ conditions as compared to the high Trp condition. However,\% of total daily calories consumed during free feeding, a measure of appetite, was higher in the low Trp + Cyp condition, 12.6+ of appetite, was higher in the low Trp + cyp condition, $1 . .01$ $2.8 \%$, than in the low Trp condition alone, $8.2+1.1 \%$, $\mathrm{p}<.0$ (df=11) suggesting a synergistic effect of Trp restriction and Cyp. Pizotifen, another 5-HT receptor blocker reduced feeding
time in a 7 mo. citrullinemic child from 180 to $130 \mathrm{~min} / \mathrm{d}, \mathrm{p}=.02$ at a dose of $0.11 \mathrm{mg} / \mathrm{kg} / \mathrm{d}$ and to $105 \mathrm{~min} / \mathrm{d}$ at $0.17 \mathrm{mg} / \mathrm{kg} / \mathrm{d}$. Decreasing oral Trp from 29 to $15 \mathrm{mg} / \mathrm{kg} / \mathrm{d}$ resulted in further improvement. In addition to good metabolic contro1, restriction of 5-HT precursors combined with antiserotonergic drugs may be useful in the treatment of appetite problems in UCD.

121 PROPERTIES OF RED BLOOD CELLS (RBC) FROM FETUSES OF 1214 DIABETIC RATS. John D. Johnson and Sandra Tris Department of Pediatrics, Albuquerque, NM.

Hyperbilirubinemia in human infants of diabetic mothers (IDM) can be explained in part by elevated bilirubin production as assessed by endogenous carbon monoxide excretion (Veco). We have explored the hypothesis that elevated Veco in IDM may result from abnormal RBC deformability and decreased life span by studying properties of RBC from fetuses of diabetic rats (FDM).

Wistar rats were made diabetic by i.v. injection of $40 \mathrm{mg} / \mathrm{kg}$ streptozotocin, mated and offspring studied at 21-days gestation. FDM were hyperglycemic and had elevated glycosylated hemoglobin vs. controls (C), but comparable serum insulin. Using polycarbonate filters with $5 \mu \mathrm{m}$ pore dia., filtration ratio (ratio of filtration time of red cell suspension to buffer) was markedly increased in FDM $(6.60 \pm 1.15$ for FDM vs. $18.4 \pm 0.10$ for $\mathrm{C}, \mathrm{p} 51.001)$. RBC survival was determined by cross-transfusion of 51 r-labeled fetal RBC to normal adult recipients: Percent injected ${ }^{5}-\mathrm{Cr}$ in circulation

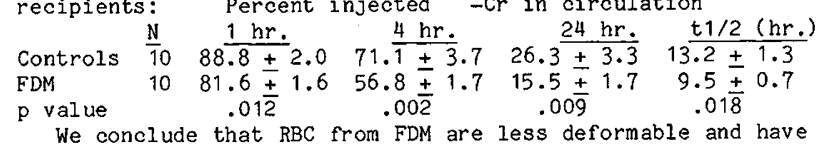
decreased survival vs. C. Since serum insulin is equivalent in FDM and $C$, these abnormalities must be secondary to hyperglycemia and/or its concomitant effects and may be the result of non-enzymatic glycosylation of critical RBC membrane proteins.

\section{LYSOSOMAL EFFLUX OF FREE SIALIC ACID: IMPLICATIONS} 1215 FOR SALLA DISEASE. Adam J. Jonas and M. Helen Huls, Medical School, Houston, Tx 77030

Salla disease is characterized biochemically by greatly increased levels of free sialic acid in lysosomes. In order to study the metabolism of free sialic acid (N-acetyl neuraminic acid, NANA) in lysosomes, highly purified lysosomes were prepared from rat liver by Percoll gradient centrifugation. These 1ysosomes were loaded with sialic acid by incubation in $250 \mathrm{mM}$ C-NANA. Lysosomal. loading was both temperature and time deLysosomes treated in this manner and then subjected to freeze/ Lysosomes treated in this manner and then subjected to freeze/ thawing lost both $90 \%$ of their sialic acidic their $\beta$-hexosaminidase activity. The lysosomal sialic acid thus taining 5,500 pmol sialic acid//mol/min $\beta$-hexosaminidase activity lost $204 \mathrm{pmo} 1 / \mathrm{min}$ or $37 \%$ of their sialic acid content over 10 minutes at $25^{\circ} \mathrm{C}$ without evidence of 1ysosomal breakage. Loss of sialic acid slowed markedly after 10 minutes to $40 \mathrm{pmol} / \mathrm{min}$. Addition of $2 \mathrm{mM} \mathrm{Mgcl}_{2} / \mathrm{ATP}$ to the lysosomes resulted in a $50 \%$ increase in the loss of sialic acid during a 10 minute incubation without change in lysosomal integrity as measured by 8 -hexosaminidase activity. These studies suggest that lysosomes may contain a transport system for the efflux of free sialic acid. Accumulation of free sialic acid in Salla disease would be consistent with defective lysosomal efflux of sialic acid.
1216 ROLE OF PLASMA GLUCOSE IN THE REGULATION OF ENDOGE$\$ 1216$ NOUS GLUCOSE PRODUCTION IN THE HUMAN NEWBORN. Satish C. Kalhan, Anita Oliven, Katherine C. King and Carlos Lucero. Case Wediatr. Metabolism, Cleveland, $\mathrm{OH}$. tan General Ho anim is high compared newborn human and animals is high compared with adults, their plasma glucose concentrations are low. The newborn frequently develop hyperglycemia in response to glucose infusions. Previous data have shown that glucose release by isolated liver from fotudy the role of glucose in the regulation of endogenous glustud, the $2.6-4.6$ cose production was examinalional age (SGA) infants. All infants were healthy and had no overt age (SGA) infants. All infants were healthy and had no overt glucose infusion by tracer dilution using $\left[6,6,2 \mathrm{H}_{2}\right]$ glucose. (mean $\pm \mathrm{SD}$ )

\begin{tabular}{|c|c|c|c|c|}
\hline & Basa & & Glucose & nfusion \\
\hline & $\frac{\mathrm{Ra}}{\mathrm{mg} / \mathrm{kg} \cdot \mathrm{min}}$ & $\frac{\text { Glucose }}{\mathrm{mg} / \mathrm{dl}}$ & $\frac{\text { Peak Glucose }}{\text { mg.dl }}$ & $\frac{\mathrm{Ra}}{\mathrm{mg} / \mathrm{kg} \cdot \mathrm{min}}$ \\
\hline AGA & $4.13 \pm 0.22$ & $61.3 \pm 10.1$ & $90.1 \pm 12.9$ & $1.07 \pm 0.58$ \\
\hline Preterm & $3.49 \pm 0.38$ & $45.5 \pm 14.1$ & $81.4 \pm 12.2$ & $1.89 \pm 0.57$ \\
\hline SGA & $4.25 \pm 0.98$ & $47.6 \pm 5.8$ & $66.1 \pm 10.9$ & $2.2 \pm 1.12$ \\
\hline $\begin{array}{l}\text { There } \\
\text { Ra durin } \\
\text { related } \\
\text { as in ho } \\
\text { newborn }\end{array}$ & $\begin{array}{l}\text { s a negative } \\
\text { glucose infu }\end{array}$ & $\begin{array}{l}\text { Lorrelation } \\
\text { ion }(r=-0 . \\
\text { lucose infu }\end{array}$ & $\begin{array}{l}\text { tween peak glt } \\
\mathrm{P}=.006) \\
\text { on. These dat } \\
\text { y plasma gluce }\end{array}$ & $\begin{array}{l}\text { cose }\left(P_{G}\right) \text { and } \\
P_{G} \text { was also } \\
\text { a show that } \\
\text { se in the }\end{array}$ \\
\hline
\end{tabular}
1217 DEVELOPING RAT BRAIN (RB) BINDS MONOIODINATED 125 ITISSUES. Michael S. Kappy, Derrel W. Clarke, Fred T. Boyd, Jr., and Mohan K. Rajzada, U. of Florida College of Med., Frank, Lilly Research Laboratories, Indianapolis.

Frank, Lilly Research Laboratories, Indianapolis. Considerable interest in the relationship between insulin and
the brain has developed since Havrankova et al reported insulin and insulin receptors in RB in 1978. There is evidence that insulin may be synthesized in RB, and that the insulin/insulin receptor system in RB is functionally separate from that in the periphery. Recently, we documented that insulin stimulates protein and nucleic acid synthesis in glia from newborn RB, and established that the developing RB is a target tissue for insulin

We studied the relative binding of monoiodinated insulin isomers (B26 and A14) to determine if membranes and cells from newmers (B26 and A14) to determine if membranes and cells from newilar to other extrahepatic insulin target tissues. RB membranes, neurons and glia bound B26 better than Al4, whereas liver plasma membranes bound both equally. Competition-inhibition curves were generated using homologous 127 I-insulin isomers. Binding of B26 was greater than A14 at all concentrations. The relative maximal binding of B26 compared to Al4 was 1.35 .

Scatchard plots of the data were curvilinear, which is characteristic of other insulin target tissues. Receptor concentrations for each isomer were similar, but affinities for B26 were greater than for Al4 at all points, suggesting that the entire differences in relative binding could be accounted for by diffdifferences in relative binding could be accounted for by diff
erences in receptor affinity for the two isomers. This is in agreement with the findings in other insulin target tissues. $\dagger 1218 \begin{aligned} & \text { SITES OF ACTION OF } \\ & \text { CHONDROCYTES. Stephen } \\ & \text { Fu-Ju Ma, M. SOMATOMEDIN ON ON }\end{aligned}$ Pediatrics, University of Arkansas for Medical Sciences, Little Rock, Arkansas.

Somatomedin $\mathrm{C} /$ insulin-like growth factor $I$ (SM-C/IGF-I) is the major regulator of cartilage growth and glycosaminoglycan (GAG) biosynthesis. We have previously shown that stimulation of sulfate incorporation into GAG by $S M$ is dependent upon protein synthesis, particularly synthesis of GAG protein core. Using a cultured chick chondrocyte system, we investigated the time necessary for stimulation by SM. Increased incorporation of thymidine into DNA occurred after a lag of 5 hours, sulfate into GAG after $1-2$ hours, and leucine into protein and uridine into RNA within 15 minutes. Because stimulation of RNA and protein synthesis are both rapid, we studied whether the protein synthesis are both rapid, we SM stimulation of RNA. stimulation of GAG biosynthesis requires SM stimulation of RNA. Actinomycin $D(5 \mathrm{ug} / \mathrm{ml}$, which inhibits RNA synthesis without
blocking SM stimulation of native GAG synthesis) and 4-methylblocking $S M$ stimulation of native GAG synthesis) and 4-methyl-
umbellifery1-B-D-xyloside ( $1 \mathrm{mM}$, which acts as an acceptor for initiation of GAG chains) were used for these studies. Addition of xyloside increased incorporation of sulfate into soluble GAG, but decreased incorporation into cell-bound GAG. The effect of SM was still present after addition of the xyloside with and without actinomycin D. We conclude that SM stimulation of protein and RNA synthesis occurs within minutes after addition protein and RNA synthesis occurs within minutes after addition
of SM, and before stimulation of sulfation or DNA synthesis. of SM, and before stimulation of sulfation or DNA synthesis. reflected by an increase in xyloside-initiated chalns. 